\title{
PENGARUH SUPERVISI KEPALA SEKOLAH TERHADAP KINERJA GURU DI SMP NEGERI 1 PARUNG KECAMATAN PARUNG KABUPATEN BOGOR
}

\section{EFFECT OF SUPERVISION OF PRINCIPAL TEACHER PERFORMANCE IN SMPN 1 PARUNG DISTRIC PARUNG BOGOR}

\author{
Darmawati1 ${ }^{1}$ R. Akhmad Munjin², G. Goris Seran³ \\ 1Jurusan Ilmu Administrasi Negara Fakultas Ilmu Sosial dan Ilmu Politik Universitas Djuanda, Jl. Tol \\ Ciawi No. 1, Kotak Pos 35 Bogor 16770. \\ ${ }^{2}$ Jurusan Ilmu Administrasi Negara Fakultas Ilmu Sosial dan Ilmu Politik Universitas Djuanda, Jl. Tol \\ Ciawi No. 1, Kotak Pos 35 Bogor 16770 \\ 3Jurusan Ilmu Administrasi Negara Fakultas Ilmu Sosial dan Ilmu Politik Universitas Djuanda, Jl. Tol \\ Ciawi No. 1, Kotak Pos 35 Bogor 16770. \\ aKorespondensi: R. Akhmad Munjin, Tel. 081329630051
}

(Diterima oleh Dewan Redaksi: 01-02-2015)

(Dipublikasikan oleh Dewan Redaksi: 01-05-2015 )

\begin{abstract}
The research method was associative. The data collection techniques used was literature and field studies. The study population amounted to 47 respondents. The sampling technique used was simple random sampling. Determination of the sample used Yamane formula so the result sampling was 32 respondents. To determine the degree of correlation was used Pearson Product Moment Correlation. The results of research recapitulation variable supervision showed the average score of 3.2 which categorized medium and the recapitulation teacher performance variables obtained an average score 4.45 which categorized very good, the product moment correlation significance test for $n=32$, standard error of $5 \%$, then the value of $r_{\text {table }}=0.349$. then $r_{\text {count }} 0.195$ the count was less than $r_{\text {table }}=0.349$, so 0.195 was a significant correlation coefficient. The research conclusion showed that the influence of principal supervising toward teacher performance by $19.5 \%$ and the remaining $80.5 \%$ was determined other factors, such as the assessment of teachers by students, delivery of teaching material according to the students opinion, incentives, teacher certification.
\end{abstract}

Key word: Supervision, Performance, Teacher.

\begin{abstract}
ABSTRAK
Tujuan Penelitian adalah mengetahui Supervisi Kepala Sekolah Terhadap Kinerja Guru di SMP Negeri 1 Parung Kecamatan Parung Kabupaten Bogor. Metode yang digunakan adalah asosiatif. Teknik pengumpulan data yang digunakan adalah studi kepustakaan dan studi lapangan. Populasi penelitian berjumlah 47 Responden. Sedangkan teknik sampling yang digunakan adalah simple random sampling (sampel acak sederhana). Penentuan sampel menggunakan rumus yamane sehingga sampel yang diperoleh adalah 32 responden. Untuk mengetahui tingkat hubungan digunakan korelasi Pearson Product Moment. Hasil penelitian variabel supervisi menunjukan skor rata-rata sebesar 3.2 yang menurut penafsiran berada pada kategori sedang dan variabel kinerja guru diperoleh skor rata-rata sebesar 4.45 yang menurut penafsiran berada pada kategori sangat baik, maka Uji signifikansi korelasi product moment untuk $n=32$, taraf kesalahan 5\%, maka nilai $r_{\text {tabel }}=0.349$. maka $r_{\text {hitung }} 0.195$ lebih kecil dari $r_{\text {tabel }}$ $=0.349$, dengan demikian koefisien korelasi 0.195 itu signifikan. Kesimpulan dari hasil penelitian bahwa analisis pengaruh supervisi kepala sekolah terhadap kinerja guru sebesar $19.5 \%$ dan sisanya $80.5 \%$ ditentukan faktor lain, seperti penilaian guru oleh siswa, penyampaian materi
\end{abstract}


pendapat dari siswa, insentif, $\quad$ sertifikasi guru.

Kata Kunci: Supervisi, Kinerja, Guru

Darmawati, 2015. Pengaruh supervisi kepala sekolah terhadap kinerja guru di smp negeri 1 parung kecamatan parung kabupaten bogor. Jurnal Governansi. 


\section{PENDAHULUAN}

Sekolah merupakan lembaga yang secara otomatis tidak mungkin melepaskan diri dari proses manajemen pendidikan atau sebuah pengelolaan. Secara riil bahwa sebuah sekolah berdiri karena adanya sebuah cita-cita atau tujuan yang ingin dicapai dan diwujudkan. Sehingga dari cita-cita dan tujuan yang telah ditetapkan mustahil akan tercapai dan berjalan secara optimal apabila proses yang berjalan tidak dikelola dan diselenggarakan secara baik dan terarah.

Peningkatan mutu pendidikan ditentukan oleh kesiapan sumber daya manusia yang terlibat dalam proses pendidikan. Guru merupakan salah satu faktor penentu tinggi rendahnya mutu hasil pendidikan mempunyai posisi strategis maka setiap usaha peningkatan mutu pendidikan perlu memberikan perhatian besar kepada peningkatan guru baik dalam segi jumlah maupun mutunya.

Istilah supervisi baru muncul kurang lebih tiga dasawarsa terakhir ini. Supervisi berasal dari bahasa inggris "supervision" artinya pengawasan. Kegiatan serupa yang dahulu banyak dilakukan adalah 1).Inspeksi (pengawasan) mencari kesalahan, seorang guru atau kepala sekolah hal ini kurang disukai, 2).Penilikan atau pengawasan tidak semata-mata mencari kesalahan akan tetapi juga memperhatikan hal yang sudah dianggap baik untuk dilanjutkan pengembangannya, 3 ). Monitoring (memantau) kegiatan untuk mengumpulkan data pelaksanaan suatu program sebagai bahan penilaian dan 4).Evaluasi untuk membandingkan suatu objek dengan kriteria yang sudah ditetapkan.

Dalam konteks sekolah sebagai sebuah organisasi pendidikan, supervisi merupakan bagian dari proses administrasi dan manajemen. Kegiatan supervisi melengkapi fungsi-fungsi administrasi yang ada di sekolah sebagai fungsi terakhir, yaitu penilaian terhadap semua kegiatan dalam mencapai tujuan. Dengan supervisi, akan memberikan inspirasi untuk bersama-sama menyelesaikan pekerjaan-pekerjaan dengan jumlah lebih banyak, waktu lebih cepat, cara lebih mudah, dan hasil yang lebih baik daripada jika dikerjakan sendiri. Supervisi mempunyai peran mengoptimalkan tanggung jawab dari semua program. Supervisi bersangkut paut dengan semua upaya penelitian yang tertuju pada semua aspek yang merupakan faktor penentu keberhasilan. Dengan mengetahui kondisi aspek-aspek tersebut secara rinci dan akurat, dapat diketahui dengan tepat pula apa yang diperlukan untuk meningkatkan kualitas organisasi yang bersangkutan.

Supervisi administrasi pendidikan bagi setiap Sekolah sangat di perlukan. Hal tersebut dilaksanakan oleh atasan kepada bawahan, yang bertujuan untuk mengevaluasi program yang telah di laksanakan. Supervisi dilakukan oleh Pengawas Sekolah kepada Kepala Sekolah dan Kepala Sekolah kepada Guru. Bagi Kepala Sekolah, melakukan supervisi terhadap guru mempunyai arti menilai apakah program yang telah di laksanakan telah mencapai tujuan atau memerlukan evaluasi untuk pembenahan. Dari supervisi dapat diketahui kelebihan atau kekurangan dari program yang telah rencanakan dan dilaksanakan.

Supervisi untuk Kepala Sekolah menilai program yang ada di sekolah. Yang bertugas melaksanakan supervisi untuk Kepala Sekolah adalah pengawas dari UPTD Pendidikan di setiap kecamatan. Supervisi administrasi pendidikan untuk Kepala Sekolah meliputi Administrasi program pengajaran yaitu Silabus, dan RPP, Administrasi kesiswaan yang meliputi Kehadiran, Keaktifan dan kemampuan dalam belajar, Administrasi kepegawaian, Administrasi keuangan dan Administrasi perlengkapan.

Supervisi Untuk guru kelas dilakukan oleh kepala sekolah pada administrasi pendidikan yang yang dibuat guru yang meliputi banyak hal. Supervisi di lakukan tiap bulan. Supervisi administrasi pendidikan meliputi absen, RPP, dafter nilai, program semester, program tahunan, kalender pendidikan, alokasi waktu, format remedial, agenda Guru dan agenda harian.

Proses supervisi penting untuk dilaksanakan secara intens oleh seorang pimpinan dalam upaya meningkatkan mutu kependidikan di Sekolah. Kepala Sekolah adalah Pemimpin bagi Sekolah yang dituntut 
memiliki kemampuan manejerial sehingga dapat mengarahkan dan mengerahkan segenap sumber daya yang ada untuk mencapai tujuan organisasi, yaitu pada pencapaian efisiensi dan efektifitas pembelajaran sehingga menjadi suatu keharusan bahwa salah satu tugas kepala sekolah adalah Supervisor, yaitu mensupervisi pekerjaan yang dilakukan oleh tenaga kependidikan.

Dalam upaya meningkatkan mutu kependidikan di Sekolah, maka Kepala Sekolah harus mampu menjadi mitra kerja yang baik, melakukan supervisi secara profesional, melakukan analisis terhadap kinerja guru secara objektif dan memberikan masukan atau rekomendasi bagi pengembangan kegiatan belajar-mengajar ke depan. Kunjungan kelas dapat digunakan oleh Kepala Sekolah sebagai salah teknik untuk mengamati kegiatan pembelajaran secara langsung. Kunjungan kelas merupakan teknik yang sangat bermanfaat untuk mendapatkan informasi secara langsung tentang berbagai hal yang berkaitan dengan profesionalisme guru dalam melaksanakan tugas pokoknya mengajar, terutama dalam pemilihan dan penggunaan metode pembelajaran, media yang digunakan oleh guru dalam pembelajaran, serta mengetahui secara langsung kemampuan peserta didik dalam menangkap materi yang diajarkan.

Tugas Guru erat kaitannya dengan peningkatan sumber daya manusia melalui sector pendidikan, oleh karena itu perlu upaya-upaya untuk meningkatkan mutu Guru untuk menjadi tenaga professional. Untuk menjadikan Guru tenaga professional maka, perlu diadakan pembinaan secara terusmenerus dan berkesinambungan serta menjadikan Guru sebagai tenaga kerja yang harus diperhatikan dan dihargai serta di akui tenaga professional Guru.

Kinerja Guru pada dasarnya merupakan kinerja atau unjuk kerja yang dilakukan oleh guru dalam melaksanakan tugas sebagai pendidik. Kualitas kinerja guru akan sangat menentukan pada kualitas hasil pendidikan, karena guru merupakan pihak yang paling banyak bersentuhan langsung dengan siswa dalam proses pendidikan/pembelajaran di lembaga pendidikan Sekolah. \begin{tabular}{lccr}
\multicolumn{2}{c}{ Keterampilan } & \multicolumn{2}{c}{ diperlukan dalam } \\
kinerja & karena & keterampilan \\
merupakan & aktivitas yang & muncul dari \\
seseorang akibat suatu proses dari & at suan \\
pengetahuan, & kemampuan, & kecakapan
\end{tabular} interpersonal, dan kecakapan teknis. Upaya dapat digambarkan sebagai motivasi yang diperlihatkan untuk menyelesaikan pekerjaan. Tingkat keterampilan berhubungan dengan apa yang "dapat dilakukan", sedangkan “ upaya" berhubungan dengan apa yang "akan dilakukan". Kondisi eksternal adalah faktorfaktor yang terdapat dilingkungannya yang mempengaruhi kinerja. Kondisi eksternal merupakan fasilitas dan lingkungan kerja yang mendukung produktivitas/kinerja Guru, interaksi antara faktor internal dengan eksternal untuk menghasilkan sesuatu dengan kualitas tertentu merupakan unsur yang membentuk kinerja.

Dalam mencapai tujuan tidak terlepas dari unsur manusia dan unsur non manusia. Oleh karena itu, kinerja yang ditunjukan oleh unsur-unsur tersebut akan menunjukan kemampuan organisasi dalam mencapai tujuan yang telah ditentukan sebelumnya. Sebagai Guru akan selalu dituntut tentang sejauh mana kinerja Guru tersebut dalam melaksanakan dan menyelesaikan pekerjaannya, apakah Guru berkinerja tinggi/memuaskan atau berkinerja rendah/jelek. Dengan demikian, seorang Guru dalam penilaian kerja oleh Kepala Sekolah selalu dihubungkan dengan kinerja.

SMP Negeri 1 Parung merupakan salah satu sekolah negeri yang berada di kecamatan Parung yang secara ekonomis dan geografis memiliki peran yang sangat penting, terutama dalam upaya pengembangan pendidikan. Berdasarkan observasi sementara pada SMP Negeri 1 Parung Kabupaten Bogor bahwa masih banyak kendala yang berkaitan dengan pelaksanaan supervisi Kepala Sekolah yang meliputi kualitas supervisi dari Kepala Sekolah yang masih tergolong rendah dikarenakan proses supervisi yang dilaksanakan tidak intens sehingga ada sebagian pengajar yang tidak membuat administrasi guru dan administrasi kesiswaan. Sehingga tujuan untuk membantu dan membina Guru belum optimal dilaksanakan 
oleh Kepala Sekolah dalam mengembangkan metode pengajaran dan prosedur pengajaran yang lebih baik, selain itu banyak Guru yang kurang berhasil dalam mengajar dikarenakan kurang termotivasi untuk mengajar sehingga berdampak terhadap menurunnya produktivitas/kinerja Guru. Berikut data tentang keahlian setiap Guru dalam bidangnya yaitu:

Tabel 1

Data ketidaksesuaian latar belakang pendidikan dengan bidang studi

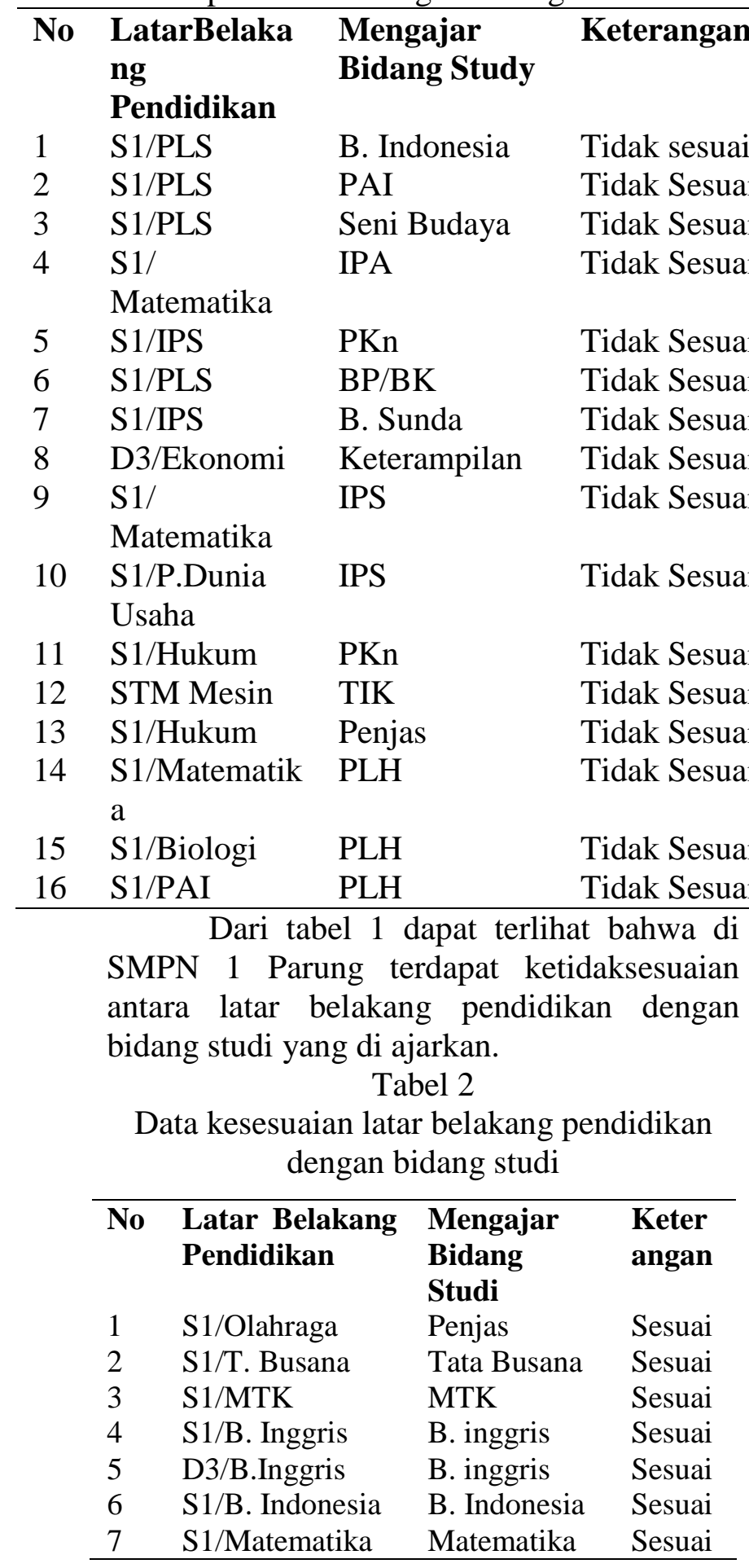

\begin{tabular}{llll}
\hline 8 & S1/B. Indonesia & B. Indonesia & Sesuai \\
9 & S1/Matematika & Matematika & Sesuai \\
10 & S1/Matematika & Matematika & Sesuai \\
11 & S1/PAI & PAI & Sesuai \\
12 & S1/IPS & IPS & Sesuai \\
13 & D1/Kesenian & Seni Budaya & Sesuai \\
14 & S1/ Biologi & IPA & Sesuai \\
15 & D3/B. Indonesia & B. Indonesia & Sesuai \\
16 & S1/B. Inggris & B. Inggris & Sesuai \\
17 & D3/Penjas & Penjas & Sesuai \\
18 & S1/Biologi & IPA & Sesuai \\
19 & S1/B.Indonesia & B.Indonesia & Sesuai \\
20 & S1/Penjas & Penjas & Sesuai \\
21 & S1/IPS & IPS & Sesuai \\
22 & S1/B.Indonesia & B.Indonesia & Sesuai \\
23 & S1/Matematika & Matematika & Sesuai \\
24 & S1/PAI & PAI & Sesuai \\
25 & S1/Sejarah & IPS & Sesuai \\
26 & S1/Fisika & IPA & Sesuai \\
27 & S1/B. Inggris & B. Inggris & Sesuai \\
28 & S1/Fisika & IPA & Sesuai \\
29 & S1/Komputer & TIK & Sesuai \\
30 & S1/Komputer & TIK & Sesuai \\
31 & S1/B.Inggris & B.Inggris & Sesuai \\
\hline & & &
\end{tabular}

Peraturan Menteri Pendidikan

Nasional Republik Indonesia Nomor 13 Tahun 2007 Tentang Standar Kepala Sekolah/Madrasah: Pasal 1 ayat (1) Untuk diangkat sebagai kepala sekolah/madrasah, seseorang wajib memenuhi standar kepala sekolah/madrasah yang berlaku nasional. Ayat (2) Standar kepala sekolah/madrasah sebagaimana dimaksud pada ayat (1) tercantum dalam Lampiran Peraturan Menteri ini. Yaitu salah satunya kompetensi supervisi yang meliputi: 1). Merencanakan program supervisi pengajaran dalam rangka peningkatan profesionalisme guru, 2). Melaksanakan supervisi pengajaran terhadap guru dengan menggunakan pendekatan dan teknik supervisi yang tepat, serta 3). Menindaklanjuti hasil supervisi pengajaran terhadap guru dalam rangka peningkatan profesionalisme guru. Untuk itu kesesuaian latar belakang pendidikan dengan mengajar bidang studi harus sama untuk meningkatkan profesionalisme guru.

Teknik Supervisi yang dikembangkan oleh Kepala Sekola SMP Negeri 1 Parung yaitu menggunakan teknik supervisi klinis yang mempunyai prinsip umum dalam landasan praktek, antara lain: 
1. Hubungan antara supervisor dengan guru adalah hubungan kolegial yang sederajat dan bersifat interaktif. Hubungan semacam ini lebih dikenal sebagai hubungan antara tenaga professional berpengalaman dengan yang kurang berpengalaman, sehingga terjalin dialog professional yang interaktif dalam suasana yang intim dan terbuka. Isi dialog bukan pengarahan atau instruksi dari supervisor/pengawas melainkan pemecahan masalah pembelajaran.

2. Diskusi antara supervisor dan guru bersifat demokratis, baik pada perencanaan pengajaran maupun pada pengkajian balikan dan tindak lanjut. Suasana demokratis itu dapat terwujud jika kedua pihak dengan bebas mengemukakan pendapat dan tidak mendominasi pembicaraan serta memiliki sifat keterbukaan untuk mengkaji semua pendapat yang dikemukakan didalam pertemuan tersebut dan pada akhirnya keputusan ditetapkan atas persetujuan bersama.

3. Sasaran supervisi terpusat pada kebutuhan dan aspirasi guru serta tetap berada didalam kawasan (ruang lingkup) tingkah laku gurudalam mengajar secara aktual. Dengan prinsip ini guru didorong untuk menganalisis kebutuhan dan aspirasinya didalam usaha mengembangkan dirinya.

\section{MATERI DAN METODE}

Menurut Sugiyono (2007:1), metode penelitian pada dasarnya merupakan cara ilmiah untuk mendapatkan data dengan tujuan dan kegunaan tertentu.Metode penelitian merupakan ilmu yang mempelajari tentang metode-metode penelitian, ilmu tentang alatalat dalam penelitian, dilingkungan filsafat, logika dikenal sebagai ilmu tentang alat-alat untuk mencari kebenaran. Bila ditata dalam sistematika, metodologi penelitian merupakan bagian dari logika. (Noeng Muhadjir, 1998:140).

Untuk mendapatkan data yang diperlukan dalam penyusunan penelitian ini, penulis menggunakan metode asosiatif, yaitu penelitian yang bertujuan untuk mengetahui hubungan antara dua variabel atau lebih. Dalam hal ini peneliti mencoba mengemukakan maupun menjelaskan apa yang ditemukan dilapangan dengan cara asosiatif. Dengan penelitian ini maka akan dapat dibangun suatu teori yang dapat berfungsi untuk menjelaskan, meramalkan, dan mengontrol suatu gejala

Menurut Sugiyono (2007: 11) yang dimaksud penelitian assosiatif adalah :

"Penelitian assosiatif merupakan penelitian yang bertujuan untuk mengetahui antara dua variabel atau lebih.Dengan penelitian ini akan dapat dibangun suatu teori yang dapat berfungsi untuk menjelaskan, meramalkan dan mengontrol suatu gejala."

\section{Teknik Penarikan Sampel. POPULASI DAN SAMPEL}

Populasi menurut Sugiyono (2008:117) adalah wilayah generalisasi yang terdiri atas obyek atau subyek yang mempunyai kualitas dan karakteristik tertentu yang ditetapkan oleh peneliti untuk dipelajari dan kemudian ditarik kesimpulannya.

Populasi dalam penelitian ini adalah guru SMP Negeri 1 Parung yang berjumlah 47 orang.

Dari populasi tersebut ditarik sampel dengan menggunakan simple random sampling (sampel acak sederhana) yaitu cara pengambilan sampel secara acak (random) dengan benar-benar memberikan peluang yang sama. Selanjutnya untuk mendapatkan besaran jumlah sampel dalam penelitian ini menggunakan teori yang dikembangkan oleh Issac dan Michael yang dikutip oleh Sugiyono (2008 : 118). Rumus yang digunakan untuk menghitung besarnya sampel yang diperlukan dalam penelitian ini adalah menggunakan rumus Yamane yang dikutip oleh Rahmat (1999 : 113) sebagai berikut :

Keterangan :

$$
n=\frac{\mathrm{N}}{\mathrm{N}\left(\mathrm{d}^{2}\right)+1}
$$

$$
\begin{array}{ll}
\mathrm{n} & =\text { Jumlah sampel } \\
\mathrm{N} & =\text { Ukuran populasi }
\end{array}
$$


$\mathrm{d}=$ Presisi (perkiraan kesalahan yang diperkirakan yaitu 0,1 )

Sumber : Yamane dalam Rahmat (1999: 113)

$$
\begin{aligned}
\mathrm{n}=\frac{N}{N\left(d^{2}\right)+1} & =\frac{47}{47(0,1)^{2}+1} \\
& =\frac{47}{0.47+1}=\frac{47}{1.47} \\
& =31.97=32
\end{aligned}
$$

Jadi jumlah seluruh responden yang terpilih yaitu 32 (Tiga Puluh Dua) orang guru SMP Negeri 1 Parung.

\section{Jenis dan Teknik Pengumpulan Data.}

Dalam melaksanakan penelitian tentunya ada beberapa tahap-tahap yang harus dilakukan dan dilalui untuk mendapatkan data yang lengkap dengan menggali informasi, adalah sebagai berikut :

1. Studi Kepustakaan

Teknik ini dilakukan dengan mempelajari berbagai literatur yang berkaitan dengan masalah yang berhubungan dengan pengawasan Kepala Sekolah terhadap kinerja Guru.

\section{Studi Lapangan}

Yaitu dengan meninjau secara langsung ketempat lokasi penelitian, penulis melakukan ini untuk mendapatkan data dan informasi yang berhubungan dengan permasalahan yang dibahas dalam Skripsi ini dengan cara :

a. Observasi adalah teknik memperoleh data dengan cara meneliti dan mengamati secara langsung pada sumber data yang akan dianalisis mengenai Pengaruh Supervisi Kepala Sekolah Terhadap Kinerja Guru Di SMP Negeri 1 Parung Kabupaten Bogor yang diteliti.

b. Wawancara adalah proses tanya jawab secara lisan (Narbuko dan Achmadi, 1997 : 70). Wawancara dilakukan dengan pimpinan dan pegawai.

c. Angket merupakan teknik pengumpulan data yang dilakukan dengan cara memberi seperangkat pertanyaan atau pernyataan tertulis kepada responden untuk dijawabnya. Menurut Sugiyono (2008:135), skala Likert adalah yang mempunyai gradasi yang sangat positif sampai sangat negatif dan digunakan untuk mengukur sikap, pendapat, serta persepsi seseorang atau sekelompok orang tentang fenomena sosial juga untuk menganalisis kuantitatif dengan menggunakan skor untuk pertanyaanpertanyaan tersebut dengan klasifikasi penilaian sebagai berikut:

Tabel 3

Klasifikasi Jawaban Skala Likert

\begin{tabular}{lll}
\hline Jawaban & Klasifikasi & Skor \\
a & Selalu & 5 \\
b & Sering & 4 \\
c & Kadang $\quad-$ & 3 \\
& kadang & \\
d & Hampir Tidak & 2 \\
e & Pernah & \\
\hline
\end{tabular}

Diharapkan dalam penelitian ini diperoleh data yang seakurat mungkin guna pemaparan hasil penelitian secara lengkap dan jelas. Dan mengungkap apa yang ada pada realitanya.

Pengolahan dan Analisis Data. Pengolahan data dilakukan menggunakan

Dalam penelitian kuantitatif analisis data merupakan kegiatan setelah data dari seluruh responden atau sumber data lain terkumpul. Kegiatan dalam analisa data adalah mengelompokan data berdasarkan variabel dan jenis responden, mentabulasi data berdasarkan variabel dari seluruh responden, menyajikan data tiap variabel yang diteliti, melakukan perhitungan untuk menjawab rumusan masalah.

Teknik analisa data dalam penelitian kuantitatif menggunakan statistik dalam penelitian Pengaruh Supervisi Kepala Sekolah Terhadap Kinerja Guru Di SMP Negeri 1 Parung Kabupaten Bogor, teknik analisa data penelitian yang digunakan yaitu deskriptif dan asosiatif.

Deskriptif digunakan untuk menganalisa data dengan cara mendeskripsikan atau menggambarkan data yang telah terkumpul sebagaimana adanya tanpa bermaksud membuat kesimpulan yang berlaku untuk umum atau generalisasi.

Asosiatif digunakan untuk mengetahui hubungan antara dua variabel atau lebih. 
Dalam hal ini peneliti mencoba mengemukakan maupun menjelaskan apa yang ditemukan dilapangan dengan cara asosiatif. Dengan penelitian ini maka akan dapat dibangun suatu teori yang dapat berfungsi untuk menjelaskan, meramalkan, dan mengontrol suatu gejala.

Untuk mempermudah analisis data dan penarikan kesimpulan maka disamping menggunakan perhitungan persentase juga dilakukan dengan menggunakan statistik sederhana yaitu mentransformasikan data kualitatif menjadi data kuantitatif. Cara ini biasanya dengan menggunakan perhitungan Weight Mean Score (WMS) yaitu dilakukan pembobotan untuk setiap jawaban pilihan. Dengan pemberian skor tersebut, maka akan diperoleh variasi jawaban yang bergerak 1-5, karena itu interval antara satu kriteria dengan kriteria lainnya yang diperoleh angka sebesar 0,8 . Angka ini diperoleh setelah adanya pengurangan dari nilai tertinggi dikurangi nilai terendah dan dibagi banyaknya alternatif jawaban. Sehingga diperoleh hasil sebagai berikut:

Tabel 4

Kriteria Penafsiran

\begin{tabular}{ll}
\hline Skor & Kriteria \\
$4,24-5,00$ & Sangat Baik \\
$3,43-4,23$ & Baik \\
$2,62-3,42$ & Sedang \\
$1,81-2,61$ & Buruk \\
$1,00-1,80$ & Sangat Buruk \\
\hline
\end{tabular}

Menurut Bakri Siregar (1981;20) data yang diperoleh dari lapangan lalu diolah berdasarkan jawaban responden melalui angket yang menggunakan rumus WMS:
Keterangan:$$
M=\frac{\sum(\mathrm{fx})}{\mathrm{n}}
$$
$\mathrm{M}=$ Perolehan angka kriteria penafsiran
$\mathrm{f}=$ Frekuensi jawaban
$\mathrm{x}=$ Pembobotan (skala nilai)
$\sum=$ Penjumlahan
$\mathrm{n}=$ Jumlah seluruh jawaban responden

Untuk mengetahui tingkat hubungan antara Supervisi Kepala Sekolah Terhadap Kinerja Guru Di SMP Negeri 1 Parung Kabupaten Bogor dilakukan pengujian hipotesis, untuk menguji hipotesis tersebut digunakan korelasi Pearson Product Moment Sugiyono (2007) dirumuskan sebagai berikut :

$$
r_{x y}=\frac{\sum x y}{\sqrt{\left(\sum x^{2}\right)\left(\sum y^{2}\right)}}
$$

Keterangan :

$$
\begin{array}{llll}
r_{x y} & = & \begin{array}{l}
\text { Koefisien korelasi "product } \\
\text { moment" }
\end{array} \\
\mathrm{n} & =\begin{array}{l}
\text { Jumlah individu dalam } \\
\text { sampel }
\end{array} \\
\mathrm{X} & =\begin{array}{l}
\text { Angka mentah untuk } \\
\text { variabel x }
\end{array} \\
\mathrm{Y} & =\begin{array}{l}
\text { Angka mentah untuk } \\
\text { variabel y }
\end{array}
\end{array}
$$

Setelah melewati tahap perhitungan, maka untuk mengetahui tingkat hubungan antara variabel $\mathrm{X}$ (Supervisi) dan variabel $\mathrm{Y}$ (Kinerja) digunakan pedoman Interprestasi Koefisien menurut pendapat Sugiyono (2007 : 149) berikut ini :

\section{Tabel 5}

Pedoman Untuk Memberikan Interprestasi Koefisien Korelasi

\begin{tabular}{ll}
\hline Interval Koofisien & Tingkat Hubungan \\
$0,00-0,199$ & Sangat Rendah \\
$0,20-0,399$ & Rendah \\
$0,40-0,599$ & Sedang \\
$0,60-0,799$ & Kuat \\
$0,80-1,000$ & Sangat Kuat \\
\hline
\end{tabular}

Sumber : Sugiyono (2007 :214)

Untuk menguji signifikasi hubungan, yaitu apakah hubungan yang ditemukan itu berlaku untuk seluruh populasi yang berjumlah 32 orang, maka perlu diuji signifikasinya. Rumus uji signifikasi korelasi product moment, yaitu :

$t=\frac{r \sqrt{n-2}}{\sqrt{1-r^{2}}}$

Hipotesis statistiknya adalah :

Ho $: \mu=0$ (tidak ada hubungan)

Ho : $\mu \neq 0$ (ada hubungan)

Ketentunnya adalah bila $r$ hitung lebih kecil dari tabel, maka Ho diterima dan $\mathrm{Ha}$ 
ditolak, tetapi sebaliknya bila $r$ hitung lebih besar $r$ tabel ( $r h>r$ tabel) maka Ha diterima tempel di sini! Materi dan metode penelitian harus dijelaskan secara terperinci pada bagian ini sehingga memungkinkan bagi peneliti lain untuk mengulang penelitian ini. Materi atau bahan yang digunakan tidak diperinci secara terpisah, melainkan harus terintegrasi dengan prosedur penelitian. Misalnya, .."responden diminta mengisi daftar pertanyaan menggunakan pensil 2B dan memilih satu dari tiga poster yang diperlihatkan oleh peneliti...", tidak perlu memerincinya seperti berikut: " Materi penelitian terdiri atas: daftar pertanyaan, pensil 2B, dan poster. Jika penelitian menggunakan produk berpemilik (seperti paten) untuk pembanding, produk dimaksud harus dituliskan dalam nama kimia yang baku atau dituliskan merk dagangnya di dalam tanda kurung jika dianggap membantu memperjelas pemahaman pembaca, namun syaratnya harus mendapat izin tertulis dari pemilik produk dimaksud sebelum dipublikasikan. Model, tipe, merk, dan produsen peralatan yang digunakan dalam penelitian harus dijelaskan. Metode dan model analisis statistik harus jelas sehingga memungkinkan bagi peneliti lain untuk melakukan pengulangan.

\section{HASIL DAN PEMBAHASAN}

Berdasarkan hasil penelitian, diperoleh bahwa supervisi Kepala Sekolah di SMPN 1 parung memperoleh skor rata-rata sebesar 3.2 dapat dikategori "sedang". Dengan kata lain dari mulai persiapan sampai pada pelaksanaan kegiatan supervisi telah dilakukan cukup sesuai dengan aturan. Berikut rekapitulasi variabel supervisi.
Tabel 6

Rekapitulasi Variabel X tentang Supervisi Kepala Sekolah
2.76 Sedang

kunjungan kelas

Teknik pengamatan observasi dengan teliti di kelas kelas

Rekapitulasi dimensi teknik observasi kelas percakap keluhan yang an dikeluarkan pribadi oleh guru

Rekapitulasi dimensi percakapan pribadi

3.71 Baik

$\begin{array}{ll}\text { Intervisi } & \text { studi } \\ \text { tasi } & \text { banding } \\ \text { (mengu } & \text { dengan } \\ \text { njungi } & \text { mengunjungi } \\ \text { sekolah } & \text { sekolah lain } \\ \text { lain) } & \text { Memperbaiki } \\ & \text { mengajar }\end{array}$

$3.59 \quad$ Baik

3.68 Baik

Rekapitulasi dimensi intervisitasi

3.63 Baik






\begin{tabular}{llll}
\hline $\mathbf{h}$ & $M$ & $\mathbf{3 . 2}$ & Sedang \\
& $=\frac{\sum \text { Skor }}{\text { Jumlah Indikator }}$ & & \\
\hline
\end{tabular}

Berdasarkan hasil penilaian terhadap kinerja guru di SMPN 1 Parung memperoleh skor rata-rata sebesar 4.45 hal ini menunjukan bahwa nilai tersebut masuk dalam kategori "sangat baik". Berikut rekapitulasi variabel Supervisi dan kinerja.

\begin{tabular}{|c|c|c|c|}
\hline No & Variabel & $\begin{array}{c}\text { Hasil } \\
\text { Penelitian }\end{array}$ & $\begin{array}{c}\text { Kriteria } \\
\text { Penilaian }\end{array}$ \\
\hline 1 & $\begin{array}{l}\text { Supervisi } \\
\text { Kepala } \\
\text { Sekolah (X) }\end{array}$ & 3.2 & Sedang \\
\hline 2 & $\begin{array}{l}\text { Kinerja } \\
\text { Guru }(\mathrm{Y})\end{array}$ & 4.45 & $\begin{array}{l}\text { Sangat } \\
\text { Baik }\end{array}$ \\
\hline
\end{tabular}

Dari tabel 4.41 dapat terlihat bahwa rata-rata dari variabel supervisi 37.1875 dan rata-rata variabel kinerja 44.6875, selanjutnya dimasukkan dalam rumus product moment sebagai berikut:

$$
\begin{aligned}
& r_{x y}=\frac{\sum x y}{\sqrt{\left(\sum x^{2}\right)\left(\sum y^{2}\right)}} \\
& r_{x y}=\frac{177.875}{\sqrt{(914.875)(910.875)}} \\
& =\frac{177.875}{30.24690067 x 30.18070576} \\
& r_{x y}=\frac{177.875}{912.8728091}=0.194851899 \\
& =0.195
\end{aligned}
$$

Dari hasil penghitungan dapat diketahui bahwa terdapat hubungan positif sebesar 0.195 antara supervisi kepala sekolah dan kinerja guru. Untuk dapat memberi interpretasi terhadap kuatnya hubungan tersebut, hubungan tersebut baru berlaku untuk sampel yang 32 orang. Untuk menguji signifikansi hubungan maka perlu di uji signifikansinya.

Berdasarkan tabel 3.4, maka koefisien korelasi yang ditemukan sebesar 0.195 termasuk pada kategori sangat rendah. Jadi terdapat hubungan yang sangat rendah antara supervisi kepala sekolah dan kinerja guru. Hubungan tersebut berlaku apabila untuk sampel 32 orang. Untuk menguji signifikansi hubungan, yaitu hubungan yang ditemukan berlaku untuk seluruh populasi, maka perlu diuji signifikansinya. Rumus uji signifikansi korelasi product moment ditunjukkan pada rumus berikut:

$$
\begin{aligned}
\mathrm{t}=\frac{\mathrm{r} \sqrt{\mathrm{n}-2}}{\sqrt{1-\mathrm{r}^{2}}}= & \frac{0.195 \sqrt{32-2}}{\sqrt{1-0.195^{2}}} \\
& =\frac{0.195 \times 5.477}{\sqrt{1-0.038}}=\frac{1.068}{0.962} \\
& =1.110
\end{aligned}
$$

$t_{\text {hitung }}$ tersebut selanjutnya dibandingkan dengan $t_{\text {tabel }}$, untuk taraf kesalahan 5\% uji dua belah pihak dan $\mathrm{dk}=32-2=30$, maka $\mathrm{di}$ peroleh $\mathrm{t}_{\text {tabel }}=0.683$.

Berdasarkan perhitungan dan yang ditunjukan pada gambar 4.43 maka dinyatakan bahwa $\mathrm{t}_{\text {hitung }}$ jatuh pada daerah penolakan $\mathrm{HO}$, maka dapat dinyatakan hipotesis nol yang menyatakan tidak ada hubungan antara supervisi kepala sekolah dan kinerja guru ditolak, dan hipotesis alternatif diterima. Jadi kesimpulannya koefisien korelasi antara supervisi dan kinerja sebesar 0.195 adalah signifikan, artinya koefisien tersebut dapat digeneralisasikan atau dapat berlaku pada populasi dimana sampel yang 32 orang diambil.

Uji signifikansi korelasi product moment secara praktis, yang tidak perlu dihitung, tetapi langsung dikonsultasikan pada $\mathrm{r}$ tabel product moment (tabel I lampiran), dari tabel I dapat dilihat bahwa untuk $\mathrm{n}=32$, taraf kesalahan 5\%, maka nilai $\mathrm{r}_{\text {tabel }}=0.349$. maka $\mathrm{r}$ hitung 0.195 lebih kecil dari $\mathrm{r}$ tabel $=0.349$, dengan demikian koefisien korelasi 0.195 itu signifikan.

Selanjutnya dihitung determinasi untuk $0.195=19.5 \%$. Hal ini berarti varian yang terjadi pada variabel kinerja $19.5 \%$ ditentukan oleh varian yang terjadi pada variabel supervisi. Pengertian ini sering diartikan pengaruh supervisi terhadap kinerja $=19.5 \%$ dan sisanya $80.5 \%$ ditentukan faktor lain, seperti penilaian guru oleh siswa, penyampaian materi menurut pendapat dari siswa, insentif, sertifikasi guru, tunjangan kegiatan, gedung, sarana dan prasarana, organisasi (yang dalam penelitian ini tidak dianalisis ). 


\section{KESIMPULAN DAN IMPLIKASI}

1. Hasil penelitian responden terhadap supervisi Kepala Sekolah di SMPN 1 parung memperoleh skor rata-rata sebesar 3.2 dapat dikategori "sedang". Dengan kata lain dari mulai persiapan sampai pada pelaksanaan kegiatan supervisi telah dilakukan cukup sesuai dengan aturan.

2. Dan hasil penilaian terhadap kinerja guru di SMPN 1 Parung memperoleh skor rata-rata sebesar 4.45 hal ini menunjukan bahwa nilai tersebut masuk dalam kategori "sangat baik".

3. Analisis pengaruh supervisi kepala sekolah terhadap kinerja guru di SMPN 1 Parung mendapatkan korelasi $19.5 \%$ hal ini berarti varian yang terjadi pada variabel kinerja $19.5 \%$ ditentukan oleh varian yang terjadi pada variabel supervisi. Pengertian ini sering diartikan pengaruh supervisi terhadap kinerja $=19.5 \%$ dan sisanya $80.5 \%$ ditentukan faktor lain, seperti penilaian guru oleh siswa, penyampaian materi menurut pendapat dari siswa, insentif, sertifikasi guru, tunjangan, jabatan, sarana dan prasarana, media pembelajaran, pembinaan.

\section{DAFTAR PUSTAKA}

Ahmad, Muhammad Arifin. 2004. "Kinerja Guru Pembimbing sekolah Menengah Umum”. Disertasi Doktor : UNJ.

Arikunto, Suharsimi. 2004. "Dasar-Dasar Supervisi”. Jakarta: Rineka Cipta

Atmowirdiwiro, Soebagja. 2000. "Manjemen Pendidikan Indoneia". Jakarta: Ardadizya Jaya.

Burhanuddin,Yusak.2005. "Administrasi pendidikan". Bandung: Pustaka setia.

Hermiati, Rita. 2006. "Supervisi Administrasi Pendidikan”. (online)
Mangkunegara, Anwar Prabu. 2001 "Manajemen Sumber Daya Manusia". Bandung: Rosda Karya.

Muhyi, Moh. Abdul dan Hadi Hudiyanto. 1993. "Pengantar Manajemen Sumber Daya Manusia”. Jakarta: Gunadarma.

Purwanto,Ngalim.2007."Administrasi pendidikan dan supervisi pendidikan". Bandung: PT Remaja Rosda Karyta.

Soetjipto dan Kosasi, Raflis. 2004. "Profesi keguruan”.Jakarta:PT Rineka Cipta.

Sugiyono. 2007. "Metode Penelitian Administrasi". Cetakan ke-18. Bandung: CV Alfabeta.

Sulistyorini, 2001. "Hubungan antara Keterampilan Manajerial Kepala Sekolah dan Iklim Organisasi dengan Kinerja Guru”. Jakarta : Ilmu Pendidikan.

Tsauri,Sofyan.2007. "Administrasi dan supervisi pendidikan”. Jember: Center for society studies.

Wahjosumidjo. 2001. "Kepemimpinan Kepala Sekolah”. Jakarta: PT Raja Grafindo Persada.

Wibowo, B.S.,Dkk. 2002. "Kiat Praktis Manajemen Pengembangan SDM untuk Pribadi, Tim, dan Lembaga dalam Meraih Sukses Dunia dan Akhirat”. Bandung: Asy-syaamil.

Timpe Dale, A. 2002. “ Kinerja “ Jakarta: Elex Media Komputindo, 1992

2010. "Akuntabilitas Kinerja Kepala Sekolah Dalam Pembelajaran Inovatif ", Jakarta : Penerbit PT. Binatama Raya

\section{Sumber Internet:}

http://uharsputra.wordpress.com/pendidikan/p engembangan-kinerja-guru/ 
http://tips-belajar-

internet.blogspot.com/2009/08/pengertian-

pengawasan.html

http://risnawatiririn.wordpress.com/2012/01/1

7/konsep-dasar-supervisi/

http://repository.usu.ac.id/bitstream/12345678

9/18546/4/Chapter\%20II.pdf

http://polowijoyo.wordpress.com/2010/02/02/ supervisi-administrasi 